\title{
The Role of Health Locus of Control in Predicting Depression Symptoms in a Sample of Iranian Older Adults with Chronic Diseases
}

\author{
Mohamadabadi $\mathrm{M}^{* 1}$, Hoseinzade $\mathrm{Y}^{2}$
}

\begin{abstract}
Introduction and purpose: The aim of this research was to predict depression and general health based on health locus of control in older adults with chronic diseases.

Materials and Methods: This correlation study used convenience sampling method to collect 100 older adults living in Shiraz city. Research instruments included General Health Questionnaire, Geriatric Depression Scale and Health Locus of Control Questionnaire. To analyze the data, multiple regression methods were applied using SPPS (version 17).
\end{abstract}

Findings: Regression analysis showed that internal control $(\beta=0.41, p<0.000)$ and believe in God $(\beta=-$ $0.20, p<0.03)$ significantly predicted general health. Additionally, our findings showed that depression can be significantly predicted by internal control $(\beta=0.37, p<0.000)$ and believe in God $\left(\beta=-0.20, p^{<}\right.$ $0.04)$.

Conclusion: According to our findings, the two components of Internal control and believe in God, in health locus of control variable's, play an important role in predicting general health status and depressive symptoms among older adults.

Key words: Elderly, Depression, Health locus of control, General health permits copy and redistribute the material, in any medium or format, provided the original work is properly cited.

1 - MSc in Clinical Psychology, Department of Clinical Psychology, School of Education \& Psychology, Shiraz University, Shiraz, Iran, (Corresponding Author). E-mail: salehmo30@yahoo.com

2 - MSc in Clinical Psychology, Department of Clinical Psychology, School of Education \& Psychology, Chamran University, Ahvaz, Iran 


\section{بررسى كانون كنترل سلامت و رابطه آن با افسردَّى و سلامت عمومى در سالمندان شهر شيراز}

\section{محمدصالح محمدآبادى" '، يحيى حسينزاده׳}

تاريخ دريافت مقاله: و وץ/\%/ هوسו تاريخ پذيرش مقاله: ه/ / ع/ هوسا

مقدمه و هدف: سالمندى مرحلهاى از زندگى انسان است كه به طور طبيعى با كاهش توانايى هاى جسمانى و روانى همـراه اسـت و

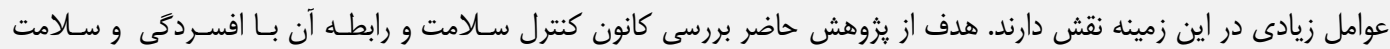
عمومى در سالمندان شهر شيراز بود

مواد و روش ها: طرح يثروشش از نوع همبستىى و جامعلى آمارى كليه سالمندان در شهر شيراز بودند. بدين منظور ..1 سالمند به

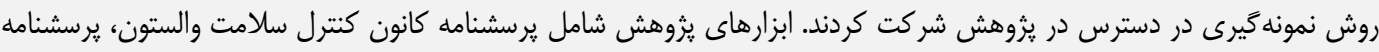

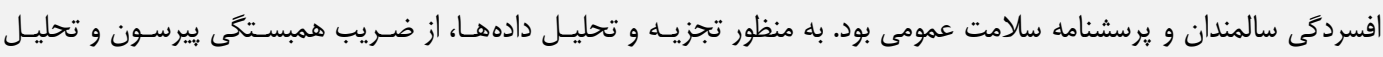
ركرسيون با نرمافزار Spss نسخه IV استفاده شد.

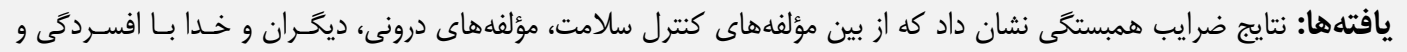
مؤلفه هاى درونى، شانس و ديكران با سلامت عمومى سالمندان رابطه معنى دار داشتند اما نتايج تحليل ركر سيون نشان داد كـه تنها

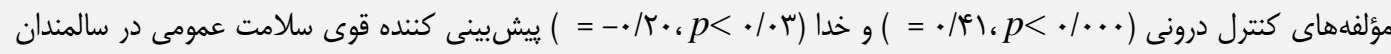

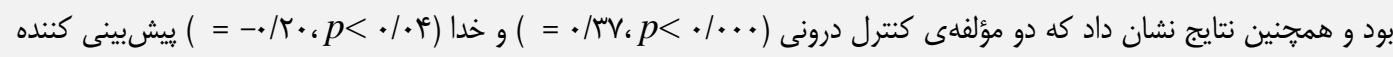

$$
\text { قوى افسردگى نيز بودند. }
$$

نتيجه كيرى: هر جه كانون كنترل سلامت افراد درونىتر باشد و باور داشته باشند كه اعتقاد به خدا بر سلامتى آنها تأثير مثبـت دارد

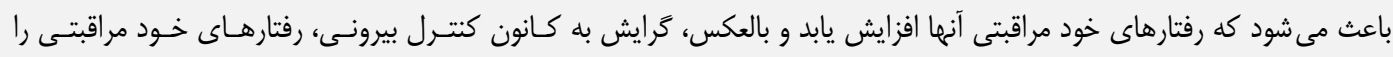
كاهش مى دهد. كليد وازهها: سالمندان، افسردگى، كانون كنترل سلامت، سلامت عمومى

$$
\text { ا- كارشناس ارشد روانشناسى بالينى، دانشكده علومتربيتى و روانشناسى، دانشكاه شيراز، شيراز، ايران }
$$

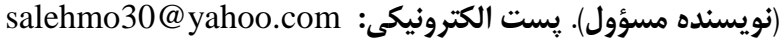
r- كارشناس ارشد روانشناسى بالينى، دانشكده علوم تربيتى و روانشناسى، دانشكاه شهيد جمر ان،، اهواز، ايران 
افراد وقوع آنها صدمهزدن به موجوديت آدمى است و در نتيجه يير شدن گا بر لب گَور گذاردن است. از نظر اريكسون و برگمن دستهاى از كشمكشهاى درونى در افراد يير وجود دارد كه ما هنگًام برخورد با آنها متوجه آن نمىشويه. ما بر بسيارى از مشكلات اجتماعى و جسمى آنهـا آخـاهى داريـم و ممكن است با وجود اينكه افراد سـالخورده كـارايى ندارنـد، بـراى آنها احساس دلسوزى كنيه. امـا مـا مـى تـوانيهم از طريـق يـافتن نمونههايى از افراد يِير كه مفيدتر و يرانرزىتر هسـتند و بيشـتر در كارهاى اجتماعى شركت دارند تصور خود را در مورد سـالخوردكان اصلاح كنيه. به هر حال ارزيابى مـا از يِيـرى، همجنـان براسـاس رفتار بيرونى آنها است و از بررسى بحرانهاى درونى آنها عـاجز هستيم. ما نمىتوانيم درى كنيم كه وقتى فرد سالمند ساكت و آرام است، احتمـالا در حـال دسـت و ينجــه نــرم كـردن بـا مهمتـرين

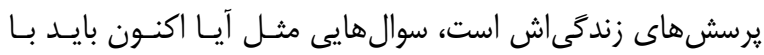

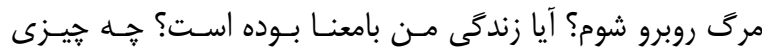
زندگى را معنادار مى كند؟ [1] سالمندى به عنوان يك ريديـده زيسـتشـناختى طبيعى و ناگزير به شمار مىآيد. رشد فزاينده و شتابان جمعيـت سـالخورده و تأثير عميقى كه اين وِديده بــر شـرايط اقتصـادى- اجتمـاعى دارد،

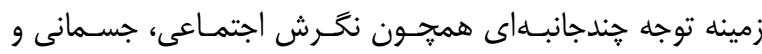
روانشناختى را فراهم نموده است [ب]. معمـولا سـالمند بـه كسـى اطلاق مىشود كه بيش از ها سال از عمرش كذشـته باشـــ [ع]. تعداد افـراد بـالاى هاء سـال در يـارهاى از كشــورهاى مختلـف در
سالمندى مرحلهاى از زندگى انسان است كـهـ بـهـ طـور طبيعـى بـاــا كاهش توانايىهـاى جسـمانى و روانسى همـراه اسـت. نـزول ايـن توانايىها وقتى با شيوه زندگى كمتحرك، غير فعال و ماشينى عصر حاضر همراه مىشود، مشكلات سالمندى را افزايش داده و از نظـر اقتصادى، اجتماعى و روانى هزينههاى سنگينى را به جامعه تحميل مى كند. همه افراد يير به يك طريق يير نمى شوند؛ به طـورى كـهـ در اين مسئله ارزش هاى اجتماعى مطرح است. در بعضى منـاطق،

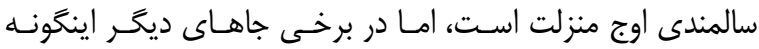
نيست. به عنوان مثـال شـنيده ايسم كـه در بــين سـرخ يوسـتان و اسكيموها، وقتى افراد يير مى شوند، قبيله خود را ترى مسى كنتـد. روايتى هم هست كه در بين عشاير ايران هم،جنين رسـمى وجـود دارد، در بين بوير احمدى ها و بختيارى هـا، سـالمندانى كـه نمـى توانند قبيله را همراهى كنند، مى كذارند و كوج مى كنند [1] . بـر اساس مستندات سازمان بهداشت جهانى افراد •ع سال و بالاتر به عنوان افراد سالمند شناخته مى شوند و براساس ايسن تقسـيم

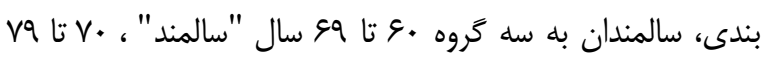
سال "سالمند سالخورده" و •^ سـال و بـالاتر "سـالمند سـالخورده تر" تقسيم مى شوند [r] معناى ييرى را عمدتاً فرهنَ تبيين مى كند. در فرهنخَها زندكى و مرگ جزء جرخه حيات محسوب شده و در درون تجربه انسانى قرار مى گيرند. يبيرى رسـيدن بـه خردمنـدى و فرزانخَى اسـت. امـا در فرهنَ غرب ييرى و مرگ مهار شدنى نيست و براى بسيارى از 
جهت سلامت روانى بسيار آسيبيذير بوده و حدود ها تا هr درصد افراد مسن مشكلات روانى مهمى دارند، به طورى كه با هـر دهـــ افزايش سن، اختلالات افسردَى افزايش مىيابـد [ع]. سـالمندان به علت كاهش اعتماد به نفس، نقصان فعاليت و حركت، از دســ دادن دوستان و نزديكان، كاهش استقلال مادى و جسمانى و ابتلا به بيمارىهاى مزمن، در معرض افسردگى و اضطراب بيشترى قرار

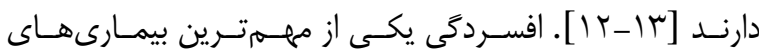
روانشناختى است كه در بررسى حالات روانى، مورد توجه بسـيارى از محققين قرار دارد. منظور از افسردگى، اختلالـى اسـت كـه دوام كافى و نشانههاى ويزه دارد و بر عملكرد شخص، تـأثير نـامطلوب مى گذارد و ير يشانى ايجاد مى كند. افسردحى يكى از شـايعترين اخـتلالات روانيزشـكى سـالمندان و از شـايعتـرين عوامـل خطــر خودكشى در سالمندان اسـت [ع 1]. توانـايى كـار و فعاليـتهـاى روزمره زندگى در افراد سالمند كاهش مىيابد كه با انزوا و تنهايى

$$
\text { همراه است [9]. }
$$

افسردحى از عمدهترين مسائل دوره سالمندى است كـه در نتيجــهـ عوامـلـ مختلــف مربــوط بـــه آخـــرين مرحلـــه زنــــــى از قبيـلـ بيمارىهـاى مـزمن، از دســدادن دوسـتان و عزيــزان و نــاتوانى در انجـام فعاليـتهــاى مـورد علاقـهـ فـرد، بسـيارى از سـالمندان را دركَيـر مى كنـــ. افـراد سـالمند در نتيجـهى ضــف بينـايى، شـنوايى و ديكـر تغييرات جســمانى، همرِنـين فشـارهاى بيرونى؛ نظيـر محـدوديت منابع مالى، احسـاس مسى كنــــ كنتـرل خويش را بر زندگى از دست دادهاند. اين قبيل مسائل و مشـكلات، منجر بــه ايجـاد هيجانـات منفى مثل غم، اضطراب، عـزت نفـس
فواصل •191 ميلادى تا هr.r ميلادى، با رشد قابـل تـوجهى در كشورهاى آلمان، آمريكا، زاين، سوئد و انحَلستان همراه بوده اسـت [0]. براساس برآوردهاى انجام شده، بـيش از •ع درصــ جمعيـت سالمندان جهان، در كشورهاى در حال توسعه زندگى مى كنند. ايـن تعداد تا سال •ه+r به •1 درصد خواهد رسيد. وضعيت در كشور ما نيز مشابه است و طى • r سال آينده، يك جهارم جمعيت كشورمان را سالمندان تشكيل خواهند داد [7]. امروزه با توسعه علوم مربوط به يزشكى، اقتصادى و اجتماعى، ميزان مرك و مير كاهش يافته و اميد به زندگى رو به افزايش است. در واقع با كذشت زمان، جمعيت جهان به سمت سالمندى ييش مىرود (اصـلانخانى و كيرنىى). بـر اين اساس يكى از مهمترين مسايل و مشكلاتى كه افراد سالمند با آن روبرو هستند، مسئله سلامت روانى است كـه تـأثير بسـزايى در سطح كيفيـت زنــدَى آنهـا دارد. بــهـ بـاور روانشناسـان، در دوران سالمندى وضع بهداشت روانى فرد سالمند در آفرينش دقايق خوب و بد تأثير فراوانى دارد و در واقع بايد يذيرفت كه رعايـت بهداشـت روانى سالمندان و ايجاد شرايط زيست محيطى براى آنـان جـز بــــ يارى بررسى دقيق رويدادهاى زندگى شان و درى صحيح شـرايط و معضلات موجود امكان خذير نيست [V]. متاسفانه اغلب افرادى كه به سن سالمندى مسىرسـند بـهـ خنــدين بيمارى و مشكل جدى سلامتى مبتلا مىشوند [9-1]. اخـتلالات روانى سالمندان از تعامل ييجيجيدهى عوامل عضـوى، روانشناسـى و اجتماعى ناشى مى شود. طبق آمار انستيتو ملى بهداشـت روانس، از شايعترين اختلالات سـالمندان مسىتـوان بـهـ افسـردگىى، اخـتلال شناختى، فوبى اشاره كرد [ع] ]. بــ دلايـل متعـددى، سـالمندان از 
رفتار واعمال آنها مى باشد و تعيين كننده سلامتى آنهـا بـهـ طـور مستقيم اعمال و رفتارهاى آنان مى باشد [IV]].

سازمان جهانى بهداشت، سلامت عمومى را سلامتى كامـل بـدنى، روانى و اجتماعى و نه فقط فقدان بيمارى يا ناتوانى تعريف مى كند. همجِنين سلامت عمومى را معادل كليهى روشها يا تدابيرى مىداند كه براى جلوگيرى از ابتلا به بيمارى روانسى بـهـ كـار مسرود. (فغفورى). بايد دانست كه روان انسان به طور مستقيم تحت تـأثير شرايط بدنى و جسمانى اوست و بـهـ طـور متقابـل جسـم انسـان و اعمال اندامها، تحت تأثير فضـاى روانسى و ذهنس قـرار مسى يــــد

"ــروهش هـاى متعـددى ارتبـاط بـين كـانون كنتــل سـلامتى و اختلالات جسمانى و روانى گَوناگَوىى را نشان داده اند، به كَونه اى كه اشكال در كنترل سلامتى به عنوان يـك مؤلفـه ى كليـدى در جندين مدل آسيب شناسـى روانس بـراى اخـتلالات خاص،مانـــــ اخـتلال شخصـيت مــرزى،اختلال افسـردمى عمــده،اختلال دو

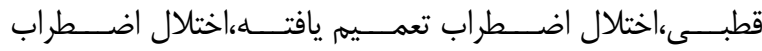
اجتماعى،اختلالات خوردن و اختلالات مرتبط با سوء مصرف مـواد

$$
\text { و الكل و ساير اختلالات جسمانى ارائه شده است [IV]]. }
$$
رشد روزافزون افراد سالمند در جهـان و ايـران و شـيوع اخـتلالات روانسى بـه ويـزّه افسـردحى در بـين آنـان [19] و كمبـود شــيد متخصصان روانيزشكى سالمندى و خدمات ويزه آنان؛ لـزوم توجـهـ به منابع بيرونى و درونسى سـالمند بـراى مقابلـهـ بـا شـرايط بيـــى احساس مىشود [•·[]. عوامل روانى - اجتماعى متعددى مىتوانند بر كنترل سلامتى تأثير بخذارند. مى توان كفت تـدابيرى كـه افـراد
يـايين، انـزواى اجتمـاعى و يأس و دلمردگى در فرد سالمند مىشود و افسردَى، بزركتـرين مشكل روانى و ييامد جدى و خطرناك اين كونـه عواطـف اسـت [10]. از جملـهـ آسـيبهـاى روانســاجتماعى كه نقش قابل ملاحظهاى در بروز حالت افسردگى دارد، از خود بيكانكَى است و اين حالتى است كـه در ميـان سـالخوردكان، قابل توجه مىباشد. بيعانكى از كار، خـانواده، همسـايههـا و انـواع گروههاى اجتماعى در خيلى از موارد، منجر به احساس طردشدگى،

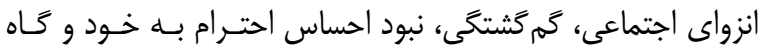

منجر به خودكشى مىشود [7]. يكى از عوامل تأثير كذار بر رفتار هاى خود مراقبتى،كانون كنتـرل سلامت است كه به اعتقاد افراد در مورد خجَـونكَى كنتـرل محـيط اشاره دارد. به عبارت ديكر، كانون كنترل، نظامى از اعتقادات است كه بر اساس آن فرد موفقيتها و شكســهـاى خـود را برحسبـ

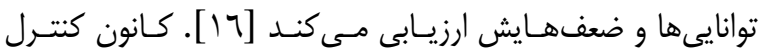
سلامتى به عنوان يك متغير مؤثر بر توسعه و ييشـفت رفتارهـاى بهداشتى و ظرفيت درمانى و تبيين مشكلات بهداشتى شناخته مى شود. كانون كنترل سلامت عبارت است از درجه باور و اعتقاد فرد به اين امر كه سلامت او تحت كنترل عوامـل درونسى يـا عوامـل بيرونى است. كسانى كه كانون كنترل سلامتى از نوع بيرونى دارند به اين امر معتقدند كه ييامدهاى معين در زندگى آنهـا بـه واسـطه نيروهايى مانند يزشكان، شانس، سرنوشت و بخت و اقبـال تعيـين مى شوند و در عوض افرادى كـه داراى كـانون كنتــل سـامت درونى هستند متتقدند كه ييامـدهاى معسين در زنـدكى در نتيجـهـ 
ميشد كه از بين كزينههاى مطـرح شــده، كزينـهاى كـه بيشـترين نزديكى با باسخ آنها را دارد انتخاب كنند.

\section{ابزار يرسشنامه سلامت عمومى (GHQ)}

يرسشنامه سلامت عمومى اولين بار توسط [YY] ، تنظيم گرديسـ. در تحقيق حاضر از فرم ب سؤالى ايـن يرسشـنامه اسـتفاده شـــه است. فرم ب ســؤالى يرسشـنامه توسـط [Yr]. از طريـق اجـراى روش تحليل عاملى بر روى فرم بلند آن طراحى شدهاست. سـؤالهاى اين يرسشنامه به بررسى وضعيت روانى فرد در يـى ماهـهى اخير مىيردازد و شامل نشانههايى مانند افكار و احساسات نابهنجار و جنبههايى از رفتار قابل مشـاهد اسـت كـهـ بــر موقعيـت اينجـا و اكنون تأكيد دارد. يرسشنامه با سؤالهاى مربوط به علائم جسمانى شروع مىشود و در ادامه سؤالهايى كه بيشتر علائم روانيزشكى را مطرح مى كنند ارائه مسىشـود. ايـن ثرسشـنامه از ع خــرده آزمـون تشكيل شدهاست كه شامل نشانههاى جسـمانى، اضـطراب و بـىخوابى، اختلال در كاركرد اجتماعى و افسردگى مس باشــ كـه هـر كدام آنها داراى V سؤال مىباشد. اين يرسشنامه براسـاس مقيـاس ليكرت (•، ا، r، r) نمرهخذارى مى شود و در نتيجه نمره كل يـى فرد از صفر تا عم متغير خواهد بـود. نمـره كمتـر بيـانخر بهداشـت

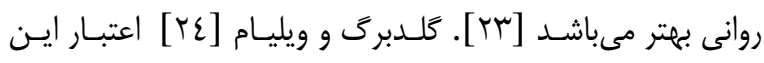
يرسشنامه را براساس اعتبار تصنيفى، ه9/• كَزارش كردنـد. تقـوى [rr] ، در تحقيق خود اعتبار اين يرسشنامه را IVI/ • و براى خرده-
براى شيوهى كنترل سلامت اتخاذ مى كنند، مشابه ديخر اختلالات روانشناختى است. با توجه به مـوارد فـوق، ايـن يـروهش در صـدد بررسى ارتباط كانون كنترل سلامت و مؤلفـهـــاى آن بـا سـلامت عمومى و افسردگى در سالمندان شهر شيراز بود.

\section{مواد و روشها}

روش تحقيق حاضـر از نـوع توصـيفىـ- همبسـتخى بـود. در ايـن تحقيق به بررسى رابطه كانون كنترل سلامت بر سلامت عمومى و افسردگى سالمندان يرداخته شد. متغير مسـتقل در تحقيـق حاضـر كانون كنترل سلامت و متغيرهاى ملاك شامل سلامت عمـومى و افسردگى بود. جامعه بزوهش در ايـن تحقيـق كليـه سـالمندان در سطح شهر شيراز است. تروه نمونسه شـامل ..1 نفــر از سـالمندان است كه با استفاده از روش نمونهَّيرى در دسترس انتخاب شــند. ملاك ورود بيماران در اين يزوهش، داشتن سـن بـالاى •ع سـال بود. لازم به ذكر است كه طرح تحقيق حاضـر در كميتـه اخلاقى بخش روانشناسى بالينى دانشخاه شيراز مورد تأييد قرار كرفته است. بعد از كسب مجوزها و موافقتهاى لازم از دانشخاه شيراز، به افراد شركت كننده توضيح داده شد كه براى انجام يك يزوهش انتخـاب مىشوند و شركت آنها در يثروهش كـاملاً اختيـارى اسـت. سـيس لـ يرسشنامهاى مربوط به متغيرهاى كانون كنترل سلامت، سلامت

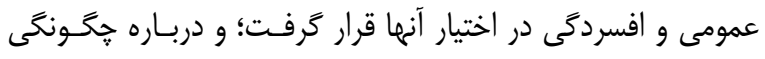
تكميل يرسشنامهها توضيحات كاملى به آنها داده شد. لازم به ذكر است كه در بعضى موارد به علت سـواد نداشـتن و يـا كـمبينـايى، كويههاى يرسشنامهها بــراى سـالمندان خوانــده و از آنهـا خواسـته

1. General Health Questionniare 
مؤلفهاى كانون كنترل درونى، شانس، قدرت ديكران و خداوند به

ترتيب • •/ •، \&9/، • • • به دست آمده است [YV]].

براى تجزيه و تحليل دادهها ابتدا از شاخصهاى آمـار توصـيفى از قبيل ميانكَين و انحر اف اسـتاندارد اسـتفاده شـــ. سـهـ از آزمـون

ضريب همبستىى بيرسون به منظور بررسى رابطه متغيرهاى كانون كنترل سلامت، سلامت عمومى و افسردىى استفاده شد. در نهايت، براى بررسى رابطه كانون كنتــل سـلامت بـا سـلامت عمـومى و افسردگى تحليـل ركرسـيون مـورد استفاده قـرار گرفـت. تمـامى تحليلهاى مذكور با استفاده از نـرمافـزار تحليـل آمـارى SPSS نسخه Vو Vورت كرفت.
آزمونهاى علائهم جسـمانى، اضـطراب و بـىخـوابى، اخـتلال در

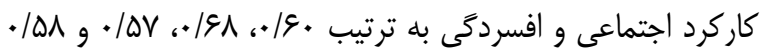

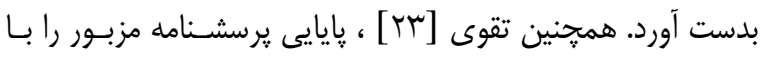
استفاده از سه روش دوباره سنجى، تصنيفى و آلفـاى كرونبـاخ بــه ترتيب • V/•، سو/• و •9/ • گزارش كرد. يرسشنامه افسردَّى سالمندان ('GDS): فرم كوتـاه (ه) سؤالى) اين يرسشنامه از فرم • بـ سؤالى آن استخراج شدهاست. اين يرسشنامه براساس קِاسخ بلى، خير نمرهكـذارى مسىشـود. ضـريب آلفاى اين يرسشنامه ع9/ • و پايايى آن به روش آزمون- باز آزمون

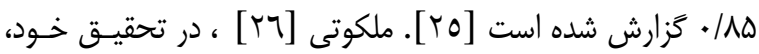

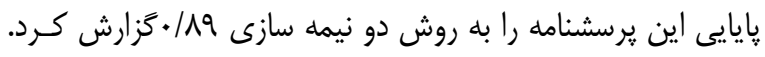
نتايج نشان داد كه فرم ال يرسشنامه افسردگى سالمندان، از پايايى و اعتبار مطلوبى براى استفاده در مطالعات همه گيرشناسى و بالينى بويزه در مناطق شهرى برخوردار است [جr]. يرسشنامه كانون كنترل سلامت 'َ والستون مشـخص كنـــه جهار حيطهى كانون كنترل درونى، شانس، قدرت ديخران و خداوند است. اين يرسشنامه داراى عَّ گَويـهـ اسـت كـهـ براسـاس مقيـاس ليكرت از ا (كاملاً موافقم) تا هـ (كاملاً مخالفم) نمرهـــارى مـىــ شود. اين آزمون از اعتبار و روايى قابل قبولى برخوردار است [IV]. روايى و پايايى اين برسشنامه در ايران توسط مشـكى و همكـاران [rV] ] مورد بررسى قرار كرفتهاست. ضريب آلفاى كرونبـاخ بـراى

1. Geriatric Depression Scale 2 . Health Locus of Control 
بالاترين ميزان نمره مربوط به سلامت عمومى و افسردگى بـود. از بين مؤلفهایى كانون كنترل سلامت هم مؤلفهاى كنترل درونى و شانس بيشترين نمره را دارا بودند.
كروه نمونه مورد يزوهش شامل .| نفر (•ه نفـر مـرد و •ه نفـر

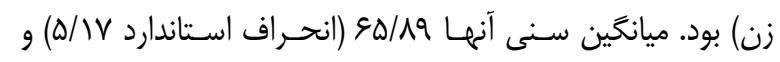
ميانگين تعداد بيمارى در اين گروه \•/ (انحراف استاندارد عم/•) بود. همجنين ميانخين مدت بيمارى افـراد شـركت كنـــه در ايـن

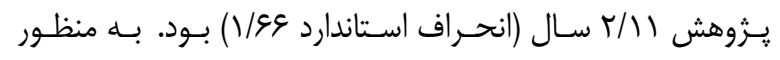
توصيف متغيرهاى كـانون كنتـرل سـلامت، افسـردگى و سـلامت عمومى از ميانگين و انحراف استاندارد اسـتفاده شـــ نتـايج آن در جدول ا نشان داده شده است. بر طبق نتايج به دست آمده

جدول (- ميانكَين و انحر اف استاندارد كانون كنترل سلامت، افسردَّى و سلامت عمومى در سالمندان ( +. (n=)

\begin{tabular}{|c|c|c|}
\hline انحراف استاندارد & ميانكَين & متغيرها \\
\hline r/ג & $18 / 0$ & كانون كنترل درونى \\
\hline$\varphi / v \Delta$ & $18 / 0$ & كانون كتترل توسط شانس \\
\hline$r / \Psi r$ & $\mid Q / 94$ & كانون كنترل توسط ديكران \\
\hline$r / . r$ & $|Q / T|$ & كانون كنترل توسط باور به خدا \\
\hline$r / \uparrow \Lambda$ & 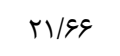 & افسردگى \\
\hline $11 / 99$ & $\Delta Q / T V$ & سلامت عمومى \\
\hline
\end{tabular}

افسردگى رابطه منفى معنىدار داشتند. هجنين نتايج نشان مىدهد كه خرده مقياسهاى كانون كنترل درونى و ديخران با سلامت عمومى رابطه مثبت معنىدار و كانون كنترل باور به خدا با سلامت عمومى رابطه منفى معنى دار دارد.
نتايج ضرايب همبستخى بين كانون كنترل سلامت با افسردگى و سلامت عمومى در جدول r نشان داده شده است. يافتهها نشان مىدهد كه خرده مقياسهاى كانون كنترل درونى و ديگران با افسردگى رابطه مثبت معنىدار و كانون كنترل باور به خدا با 


\section{جدول r- ضرايب همبستخى بين افسردكى، سلامت عمومى و مؤلفه هاى كنترل سلامتى}

\begin{tabular}{|c|c|c|}
\hline سلامت عمومى & افسردگى & متغيرها \\
\hline$\cdot / \mathcal{A}^{e} * *$ & $\cdot / \mathbb{C} Q * *$ & كانون كنترل درونى \\
\hline$-.1 \cdot 1$ & .1 .9 & كانون كنترل توسط شانس \\
\hline$\cdot|\Gamma| * * *$ & $\cdot / \Gamma \cdot * * *$ & كانون كنترل توسط ديخران \\
\hline 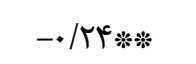 &.$- / 19 *$ & كانون كنترل توسط باور به خدا \\
\hline
\end{tabular}

$$
\begin{aligned}
& { }^{*} p<\cdot / \cdot \Delta \\
& { }^{* * *} p<\cdot / \cdot 1 \\
& { }_{*}^{* * * *} p<\cdot 1 \cdot \cdot 1
\end{aligned}
$$

تبيين كنند. امّا نتايج ضرايب بتـا نشـان داد كـه تنهـا دو مؤلفهـى به منظور بيشبينى سلامت عمومى بر اساس مؤلفـهــاى كـانون

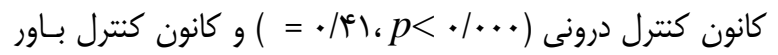
كنترل سلامت، از آزمون تحليل رگرسيون اسـتفاده شـــ نتـايج در

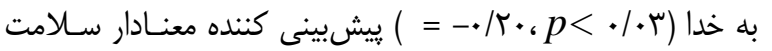
جدول ب نشان داده شده است. نتايج نشان داد كه مؤلفههاى كانون

\begin{tabular}{|c|c|c|c|c|c|c|}
\hline$F$ & $R^{2}$ & $P$ & $\beta$ & $b$ & $\mathrm{~T}$ & متغيرها \\
\hline \multirow{4}{*}{ 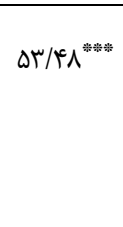 } & \multirow{4}{*}{.$/ \mu}$. &.$/ \ldots$ &.$/ 41$ & $1 / T \Delta$ & FT/FT & درونى \\
\hline & & $\cdot / \mathrm{N}^{\mathrm{C}}$ & - &.$- / \cdot v$ & & شانس \\
\hline & & $1 / \cdot 1$ &.$/ 19$ & עצ/. & $1 / v 9$ & ديخران \\
\hline & & r.|. & $-\pi$. & .109 & $-r / I Q$ & خدا \\
\hline
\end{tabular}

جدول r- نتايج تحليل رترسيون به منظور بيشبينى سلامت عمومى براساس مؤلفههاى كانون كنترل سلامت ( +. = (n)

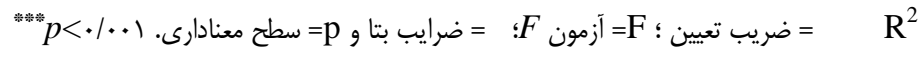

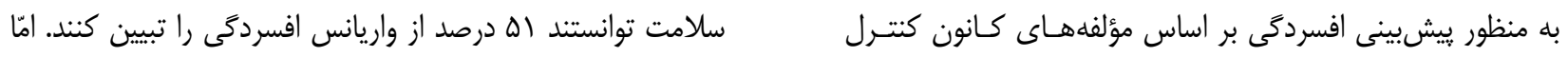

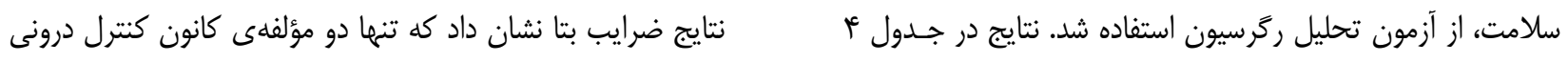
نشان داده شده است. نتايج نشان داد كه مؤلفهاى كـانون كنتـرل 


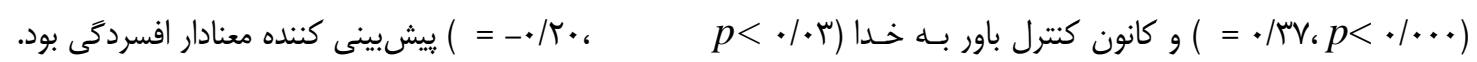

جدولع_ نتايج تحليل رترسيون به منظور بيشيبنى

\begin{tabular}{|c|c|c|c|c|c|c|}
\hline$F$ & $R^{2}$ & $P$ & $\beta$ & $b$ & $\mathbf{T}$ & متغيرها \\
\hline \multirow{4}{*}{ 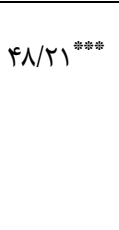 } & \multirow{4}{*}{.$|\Delta|$} &.$/ \ldots$ & $\cdot / \Psi v$ & $\cdot / \pi F$ & $r / 9$ & درونى \\
\hline & & גז/. & $.1 \cdot 1$ & .1 .4 & $\cdot / A V$ & شانس \\
\hline & & rו/. &.$/ 1 F$ & . & V/ar & ديخران \\
\hline & & .1 .4 & $-* / r$. &.$- / N$ & $-r / \cdot \Lambda$ & خدا \\
\hline
\end{tabular}

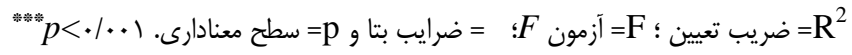
$(n=1 \cdots)$

افسردگى براساس مؤلفههاى كانون كنترل سلامت

\section{بحث و نتيجه كَيرى}

همانطور كه مىدانيم افسردحى شـايعتـرين مشـكل روانس در سالمندان است كه كيفيت زندَّى آنها را مختل مى كنـد و عـدم تشخيص و درمان اين اختلال بر زنـــى شـخص سـالمند اثر مى كذارد و باعث مشكلات فراوان و در نهايست خودكشى وى

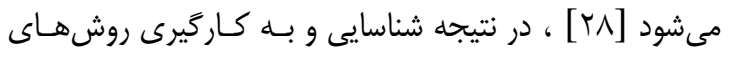
درمانى در كاهش خطرات براى سالمندان مفيد مىباشد. نتـايج

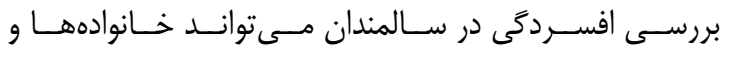
سياستخزاران را در برنامهريزىهاى آينده و رسـيدن بـهـ سـطح بالاترى از بهداشت در اين گروه يارى نمايد و مطالعه افسردگى در اين گروه به شناسايى بهتر و بيشتر عوامل خطر و استفاده از انها جهت شناسايى افراد در معـرض خطـر كمـى مسىنماينـد [rq]. يكى از مسـائل مهـهم موفقيـت در جلـو گيرى و درمـان
نتايج تحليل رگرسيون در رابطهى متغير كانون كنترل سـلامت با متغيرهاى افسردگى و سلامت عمومى نشان داد كـه مؤلفـهـهاى كنترل درونى و خدا (به طور منفى)، توانستند افسـدمَى و سلامت عمومى در سالمندان را يـيشبينسى كنــد. نتـايج ايـن تحقيق با مطالعات فرنج [Yی] و نـودهىمقـدم [Yq] همســ

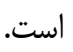
بررسى يرسشنامه افسردگى در سالمندان نشـان مسى دهـــ كـهـ عها دهرصد از افراد نمونه دهار افسردگى هستند. در ايـن بـين سهم زنان از اين كل برابر بود با ب نفر افسردگى نرمال، TV نفر افسردگى متوسط و يك نفر هم دجار افسردگى شديد بـود. سهم مردان هم به ترتيب برابر با س؟، هT و T بود. 
در واقع كانون كنترل درونى سـلامت و اعتقـاد بـهـ نقـش خــدا

باعث احساس كنترل مى شود و استرس افراد را كاهش ميدهد.

زيدنر [ [اب] ، نشان داد كسانى كـه بـه لحـاظ كـانون كنتـرل

درونى امتياز زيادى كسب كرده اند، تمايل بيشترى به در هـيش

كرفتن رفتارهايى دارند كه موجـب ييشـخيرى از بيمـارى هـا و

ارتقاى سلامت مى شـود و در مقايسـه بــا افـراد داراى كـانون

كنترل بيرونى به ميزان بيشترى به رفتارهاى يـيش كيرانـه اى

مانند رعايت عادات غذايى خوب و انجام دادن معاينات بزشكى

مى يردازند. با توجه به نتايج به دست آمـده، קهنانجـهـ در صـدد

دستيابى به نتـايج بهتـر و ارتقـاى رفتارهـاى خـود مراقبتى و

سلامت بيماران باشيم جـا دارد دوره هــاى آموزشى در جهـت

توانمندسازى اين افراد گَنجانده شود.
بيمارىهاى روانى سالمندان ارائهى خــدمات بــه ايـنـ گَـروه در قالب يك تيم توانبخشى شامل يزشـى متخصـص روانيزشـى سالمندان، مددكار اجتماعى، يرستاران كاردرمان فيزيوتراييست و روانشناس مىباشد [10]. يافتههاى حاصل از يثوهش حاضر در خصـوص ارتبـاط كـانون كنترل سلامت با سلامت عمومى و افسردگى در افراد سـالمند نشان دهنده رابطه معنى دار بين آنها مىباشد؛ بدينصـورت كـهـ هر خه كانون كنترل سلامت افراد، درونى و اعتقادشان به خــدا مبنى بر تأثير او بر روى سلامتى بيشتر باشــ، رفتارهـاى خـود مراقبتى افزايش مىيابد و گرايش بـه كـانون كنتـرل بيرونس، رفتارهاى خود مراقبتى را كاهش مىدهد. در تبيين اين امر بايد

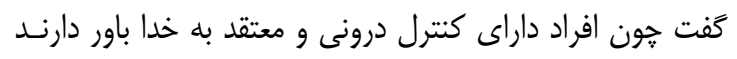
كه سلامتى، بهداشت و كيفيـت در دسـت خـود آنهاسـت و از

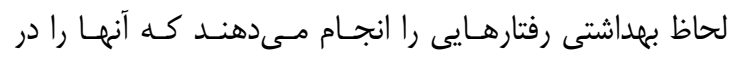

تشخيص و كنترل بيمارى كمك مى كند. سيونخروس' [•r] ، ، نيز در ارتباط بين كانون كنترل سلامت دريافتند كه افراد داراى كانون كنترل سلامت درونى بالا، استرس و افسردگى كمترى دارند در حالى كه افراد داراى كـانون كنتـرل سـلامت بيرونىى اضـطراب و افسـردمى بيشـترى داشـته و سـطوح بـالاترى از بيمارى و يريشانى روانى را نشـان مسى دهنـــ. در ضـمن افـراد داراى كنتـرل درونـى، عـزت نفـس بــالاترى دارنســ و كمتـر رفتارهاى ناسالم، از آنها سر مى زند.

2. Zeidner

1. Cvengros 


\section{- References}

1. Shamloo S. Mental health. 3rd. Tehran:Development publications; 2002.P.205-207.

2. Mirzaie M. Mortality and morbidity levels and developing a model. Scientific Information Database 1998;1: 107-118. (Persian)

3. Robertson MC, Campbell JA, Gardner MM. Preventing Injury and increase quality of life in older people: A meta analyses of individual-level data. Journal of the American Geriatrics Society. 2004; 14 (20):118-21.

4. Poorjafari H, Abaie HR. Assess and compare the rate of aging in Iran. Congress of aging examining issues in Iran. 2002; 37-41. (Persian)

5. Rahimi A. Exploring the nature of elderly people life style: A grounded theory. Iranian Journal of Ageing. 2016 Jan 15;10(4). (Persian)

6. Allahyari T, Mirgholikhani N. Examine the social factors affecting depression among elderly women in Kahrizak nursing home. Journal of Social Sciences. 2014: 70: 14-18. (Persian)

7. Rezaie S, Manoochehri M. Evaluation and Comparison of mental disorders of ageing living in a nursing home with ageing living in nursing homes in Tehran. Iranian Journal of Ageing. 2008: 3(7). (Persian)

8. Carney J, Faught BE, Hay J, Wade TJ, Corna LM. Physical activity and depressive symptoms in older adults. Journal of Physical Activity and Health. 2005 Jan 1;2(1):98-114.

9. Netz Y, Wu MJ, Becker BJ, Tenenbaum G. Physical activity and psychological well-being in advanced age: a meta-analysis of intervention studies. Psychology and aging. 2005 Jun;20(2):272.

10. Manzoori L, Anahita B, Marasi MR. Depression and associated factors in the elderly Isfahani. Iranian Journal of Ageing. 2010: 4(14): 27-33. (Persian)

11. Ingersoll B, Silverman A, Cooperative group psychotherapy for the aged.Gerontologist.1978; 18(2):201-206.

12. Lang AJ, Stein MB. Anxiety Disorders: How to recognize and treat the medical symptoms of emotional illness.Journal of Geriatrics. 2001; 56(5):24-7, 31-4.

13. Chop WC, Farrell G, Miller WC. Social aspect of aging In. Nursing care of older person. Philadelphia: McGraw Hill; 2001, p. 1115-29. 
14. Bahram ME, Pourvaghar MJ, Akkasheh G. The effect of eight weeks pilates training on reducing depression among elderly male; retired workman. Journal of Nursing elderly. 2014; 1(2). (Persian)

15. WHO. Quality health care for the elderly: mental health and aging. Module 10. 1995; 1-12.

16. Rotter JB. Generalized expectancies for internal versus external control of reinforcement. Psychological monographs: General and applied. 1966;80(1):1.

17. Zahednezhad H, Poursharifi J. Relationship between health locus of control, memory, and physician- patient relationship with satisfication of treatment in type II diabetes patients. Journal of Nursing and Midwifery. 2011:9(2). (Persian)

18. Narimani M, Ghafari M, Abolghasemi A, Ganji M. Comparison of locus of control and mental health in professional and non-professional athletes. Harkat Journal. 2006; 30(30): 15-28. (Persian)

19. Ebrahimi A. The relationship between depression of elderly nursing home residents with attitude and practice their religious. Research in Medical Sciences. 2003; 8(1): 94-95. (Persian)

20. Bahrami F, Ramezani farani A. Elderly Mental Health in the Quran and Hadith. Geritric Journal. 2009; 4(11): 70-83. (Persian)

21. Goldberg D. The Detection of Psychiatric Illness by Questionnaire. Maudsley Monograph. 1972.

No. 21. Oxford: Oxford University Press.

22. Goldberg DP, Hillier VF. A scaled version of the General Health Questionnaire. Psychological medicine. 1979 Feb 1;9(01):139-45.

23. Taghavi MR. Study the validity and reliability of public health questionnaire. Psychology Journal. 2002; 5(4): 381-398. (Persian)

24. Williams P, Goldberg DP. A user's guide to the General Health Questionnaire. Berkshire: NFER, Nelson. 1988.

25. Yesavage JA, Brink TL, Rose TL, Lum O, Huang V, Adey M, Leirer VO. Development and validation of a geriatric depression screening scale: a preliminary report. Journal of psychiatric research. 1983 Dec 31;17(1):37-49.

26. Malekooti K, Fathollahi P, Mirabzade A, Salavati M, Kahani S. Normalization of the Geriatric Depression Scale (GDS); the form of 15 questions in Iran. Research in Medical Sciences. 2006; 30(4): 361-368. (Persian) 
27. Moshki M, Ghofranipour F, Azadfallah P, Hajizadeh EB. Validity and reliability of the multidimensional health locus of control (Form B) scale in Iranian medical students. The Horizon of Medical Sciences. 2006 Apr 15;12(1):33-42. (Persian)

28. French DG. Avoiding adverse drug reactions in the elderly patient: issues and strategies. The Nurse practitioner. 1996 Sep 1;21(9):90-107.

29. Nodehi Moghadam A, Ehsanifar F. Study of physical movement disorders among elderly who come to the rehabilitation center of Behzisti of Tehran. Salmand Journal. 2006; 1(2): 123 127. (Persian)

30. Cvengros JA, Christensen AJ, Lawton WJ. Health locus of control and depression in chronic kidney disease: a dynamic perspective. Journal of health psychology. 2005 Sep 1;10(5):677-86.

31. Zeidner, M. Coping with distress and relation between locus of control, emotional intelligence \& achievement motive in American nurses. Journal of nursing. (2008); 22: 89- 108. 